\title{
Serum vitamin D and anti- mullerian hormone levels in Iraqi infertile women at Baghdad city
}

\author{
Omar F. Abdul-Rasheed ${ }^{1 *}$, Noor M. Ali ${ }^{1}$, Enas Adnan Abdulrasul ${ }^{2}$ \\ ${ }^{1}$ Department of Chemistry and Biochemistry, College of Medicine, Al-Nahrain University, Baghdad, Iraq \\ ${ }^{2}$ Department of Obstetrics and Gynecology, College of Medicine, Al-Nahrain University, Baghdad, Iraq \\ *Corresponding author E-mail: omar.rasheed@colmed-alnahrain.edu.iq
}

Copyright $\odot 2015$ Omar F. Abdul-Rasheed et al. This is an open access article distributed under the Creative Commons Attribution License, which permits unrestricted use, distribution, and reproduction in any medium, provided the original work is properly cited.

\begin{abstract}
Background: Reproductive failure is a significant public health concern. Although relatively little is known about factors affecting fertility, a growing body of literature suggests that environmental \& lifestyle factors play an important role. Recent studies suggest that vitamin D may play a role in human reproduction. Exact mechanisms whereby vitamin D may participate in the regulation of reproductive physiology remains far from clear.

Objective: To validate the potential of vitamin D as a biomarker for prediction of female infertility and to study the correlation between vitamin $\mathrm{D}$ and Anti- Mullerian hormone.

Methods: A case- control study was conducted at Department of Chemistry and Biochemistry, College of Medicine, Al- Nahrain University, Al- Kadhmiya, Baghdad, Iraq from June 2013 till July 2014. Seventy three subjects were enrolled in this study. Thirty five primary infertile women with mean age (25.4 4.91 years), and thirty eight agematched apparently healthy women as controls with mean age (27.3 \pm 3.72 years). Fasting blood samples were collected in the morning at 8:00 am from all participants. Vitamin D was measured by high-performance liquid chromatography technique and Anti- Mullerian hormone was measured by enzyme- linked immunosorbent assay.

Results: Vitamin D levels was significantly decreased in the infertile women group compared with fertile control group $(35.38 \pm 5.83 \mathrm{ng} / \mathrm{mL})$ versus $(49.99 \pm 12.90 \mathrm{ng} / \mathrm{mL})$ respectively. Vitamin D correlated significantly $(\mathrm{r}=+0.86 ; \mathrm{p} \leq 0.05)$ with anti-mullerian hormone and anti- mullerian hormone shows a significant negative correlation with body mass index $(\mathrm{r}=-0.78 ; \mathrm{p} \leq 0.05)$.

Conclusion: A novel relationship was found between circulating Anti- Mullerian hormone and vitamin D in plasma samples of infertile women.
\end{abstract}

Keywords: Vitamin D; Female Infertility; Anti-Mullerian Hormone; Mullerian Inhibiting Substance; Ovarian Reserve.

\section{Introduction}

Vitamin D is a steroid substance plays a key role in calcium and phosphorus metabolism [1-3]. Its main actions include intestinal calcium absorption and renal calcium reabsorption, as well as a direct effect on chondrocyte and osteoblast differentiation and subsequent bone formation [3]. The vitamin D precursor (7- dehydrocholesterol) is a normal intermediary in the cholesterol pathway and is present in the skin [1].Ultraviolet-B Ultraviolet-B radiation induces conversion of 7-dehydrocholesterol to pro vitamin $\mathrm{D}_{3}$, which spontaneously isomerizes to vitamin $\mathrm{D}_{3}$ (cholecalciferol) [1].

Vitamin $\mathrm{D}_{3}$ is released into circulation and transported by the vitamin D-binding protein (VDBP). Approximately 80$90 \%$ derive from sunlight-induced production in the skin. There is also a small amount of the body's total vitamin D derived from diet and or supplements [1]. This may derive from plants or fungi containing vitamin $\mathrm{D}_{2}$ (ergocalciferol) or flatly fish or cod-liver oil containing vitamin $\mathrm{D}_{3}$ (cholecalciferol) [1].

In north America and western Europe only small amounts of vitamin D, a fat soluble steroid hormone, enter the metabolic circle via dietary uptake (eg. from fish) [4]. 
The main source (about 95\%) is vitamin $\mathrm{D}_{3}$ (cholecalciferol) that is photochemically synthesized in the skin by ultra violet radiation. Thermal conversion of pro- vitamin $\mathrm{D}_{3}$ (7-dehydrocholesterol) leads to pre-vitamin $\mathrm{D}_{3}$, which isomerizes into cholecalciferol. Cholecalciferol is bound to serum vitamin D binding protein (DBP) and through a two steps enzymatic pathway involving 25- hydroxylase of the liver and 1 $\alpha$-hydroxylase (CYP 27B1) of the kidney \&extra renal tissues, it is converted to the biologically active hormone, calcitriol $\left(1 \alpha, 25(\mathrm{OH})_{2} 25(\mathrm{OH})\right.$ two $\left.\mathrm{D}_{3}\right)[4,5]$.].

Biological actions of vitamin D are mediated through the vitamin D receptor (VDR) that is distributed across various tissues including skeleton, parathyroid glands, as well as reproductive tissues [1].

A seasonal distribution in human natural conception and birth rates has been consistently demonstrated, showing a peak conception rate during summer in northern countries with strong seasonal contrast in luminosity [4].Experimental Experimental studies have demonstrated that the ovary is a target organ for $1,25(\mathrm{OH})_{2} \mathrm{D} 3$ raisingthe possibility that this active metabolite of vitamin $\mathrm{D}_{3}$ might play a role in modulating ovarian activity [6].

Experiments investigating the significance for fertility and reproductive capacity, demonstrate that $25(\mathrm{OH}) \mathrm{D} 3 \mathrm{deficient}$ female rats had reduced fertility rates, decreased litter sizes and compromised mating behavior [7].

Infertility is the inability of a non- contracepting couple to achieve pregnancy within one year of regular unprotected sexual intercourse [8], [9]. About 25\% of couples do not achieve pregnancy within one year, $15 \%$ of these couples seek medical treatment for infertility and less than $5 \%$ remain unwilling childless [9].

Infertility is a major cause of concern during recent times and can be due to male or female factors [9], [10]. However, in many couples, both male and female are implicated with the predominancy of female factor [10, 11]. In an extensive review, effects of vitamin D on fertility of males and females, have been analyzed, and it has been concluded that optimum level of this vitamin is crucial for the healthy reproductive state of both the sexes [10], [12].

Among women, vitamin D has been reported to regulate the concentration of Anti- Mullerian hormone (AMH) in blood [10], [13].Anti- Anti Mullerian hormone, also known as the Mullerian inhibiting substance, is a dimeric glycoprotein exclusively produced by granulosa cells of preantral (primary and secondary) and small antral follicles [14], [15]. The number of small antral follicles is directly related to the total size of the primordial follicle pool [15]. Measurable quantities of AMH appear in serum and with the decrease in the number of antral follicles with age, AMH serum levels also become diminished [15], [16]. AMH serum levels represent ovarian quantitative reserve in vitro fertilization (IVF) patients and may provide an index of age at menopause [15], [17-, 19]. However, it is currently not known if serum AMH levels also reflect oocyte quality and the chance of successful live birth pregnancy [19].

The purpose of this study was to elucidate the role of vitamin D in female reproduction and to assess if any associations existed between vitamin $\mathrm{D}$ levels and ovarian reserve.

\section{Methods}

This case- control study was approved by the ethics committee of the College of Medicine, AL-Nahrain University. The written informed consent was obtained from patients and controls. The study was conducted in the Department of Chemistry \& Biochemistry, College of Medicine, AL-Nahrain University, Baghdad -Iraq from June 2013 to July 2014. Seventy three participants were included in this study. The cases were 35 women suffering from primary infertility, and 38 women were taken as age- matched apparently healthy controls. The control group consisted of healthy women with one or more successful pregnancies, without any obstetrical or medical problems like hypertension or diabetes mellitus. Study group consisted of all those women who were infertile for more than one year, have body mass index (BMI) less than 25, regular menstrual cycle, normal pelvic examination findings and no post history of pelvic inflammatory disease. Exclusion criteria were male factor subfertility.

A venous blood sample (five $\mathrm{ml}$ ) was collected in fasting state from antecubital vein of each case and control subjects. The blood sample was kept undisturbed for at least 15 minutes \& was then centrifuged at $3000 \mathrm{rpm}$ for $10 \mathrm{~min}$. Serum samples then were stored at $-20^{\circ} \mathrm{C}$ for analysis of vitamin D and Anti- Mullerian hormone.

Reversed phase HPLC (LC-10AD, Shimadzu, HPLC 1991 model -7125, Kyoto-Japan) was used as follows: the vitamin $\mathrm{D}$ was isolated from the serum by liquid -liquid extraction using n-hexane solvent, concentrated by evaporation under nitrogen stream and reconstituted with HPLC grade ethanol. The reconstituted sample $(50 \mu l)$ was injected into the chromatography system on a C18- CLC-ODS column of diameter 4. 6mm (Shimadzu, Japan) with a mobile phase of methanol: water (95:5). Vitamin D was detected spectrophotometrically at $254 \mathrm{~nm}$. The column was re- equilibrated with the mobile phase for 5 minutes before injection of the next sample. In order to check the reproducibility of the method, some samples were injected consequently, twice. To verify the assay accuracy, standard analytes were injected for every 15-20 test samples. Serum Anti- Mullerian hormone (AMH) was assayed using the enzyme- linked immunosorbent assay (ELISA) kit (Cusabio, Cosmo Bio, Carlsbad, CA). The assay sensitivity for AMH was $0.375 \mathrm{ng} /$ $\mathrm{mL}$, and the intra- and inter assay coefficients of variation were $7.1 \%$ and $9.8 \%$ respectively.

\section{Statistical analysis}

Continuous data are presented as mean \pm SD. Differences between the patients and the control group for continuous variables was assessed with a student's t- test. Correlation between vitamin D and anti- Mullerian hormone level was evaluated with a Pearson correlation coefficient. Statistical analysis was performed by SPSS software (Statistical 
package for the social sciences, version 18.0, SPSS Inc, Chicago IL). A p value of $\leq 0.05$ were considered statistically significant.

\section{Results}

In total, 73 subjects were enrolled in this study, including 35 infertile women and38 healthy women. Among the infertile women, all were complaining of primary infertility. Demographic profile of both the groups is shown in table (1).

Table 1: Demographic Profile (N=73)

\begin{tabular}{llll}
\hline Variables & Primary infertile women $(\mathrm{n}=35)$ & Controls $(\mathrm{n}=38)$ & $\mathrm{P}$ value \\
\hline Age $($ years $)$ & $25.4 \pm 4.91$ & $27.3 \pm 3.72$ & 0.11 \\
BMI $\left(\mathrm{kg} / \mathrm{m}^{2}\right)$ & $24.31 \pm 3.78$ & $24.8 \pm 2.06$ & 0.66 \\
Duration of marriage (years) & $3.5 \pm 2.1$ & $4.6 \pm 3.1$ & 0.09 \\
Smoking * & $(0 \%)$ & $(0 \%)$ & \\
Education* & & & \\
Educated & $21(60 \%)$ & \\
Uneducated & $14(40 \%)$ & $6(26 \%)$ \\
Residence* & & $17(0 \%)$ \\
Rural & $8(32 \%)$ & $16(0 \%)$ \\
Urban & $17(68 \%)$ & $7(0 \%)$ \\
Occupation* Housewife Working & $20(0 \%)$ &
\end{tabular}

- $\quad(*)$ Result is expressed as frequency and percentages.

Table 2 shows the mean fasting serum vitamin D level which was significantly lower $(\mathrm{p}<0.05)$ in primary infertile group $(35.38 \pm 5.83 \mathrm{ng} / \mathrm{mL})$ in comparison with this level in controls $(49.99 \pm 12.90 \mathrm{ng} / \mathrm{mL})$.

Anti- Mullerian hormone $(\mathrm{AMH})$ was significantly $(\mathrm{p}<0.05)$ decreased in infertile group $(1.21 \pm 0.16 \mathrm{ng} / \mathrm{ml}) \mathrm{compared}$ with its level in control group $(1.54 \pm 0.26 \mathrm{ng} / \mathrm{ml})$ as shown in table (2).

Table 2: Biochemical Parameters

\begin{tabular}{|c|c|c|c|}
\hline parameter & Primary infertile women $(n=35)$ & Controls $(n=38)$ & $\mathrm{P}$ value \\
\hline Vitamin D (ng/ml) & $35.38 \pm 5.83$ & $49.99 \pm 12.90$ & $<0.05$ \\
\hline $\mathrm{AMH}(\mathrm{ng} / \mathrm{ml})$ & $1.21 \pm 0.16$ & $1.54 \pm 0.26$ & $<0.05$ \\
\hline
\end{tabular}

The infertile patients were categorized to different groups according to the level of vitamin D as shown in figure (1)

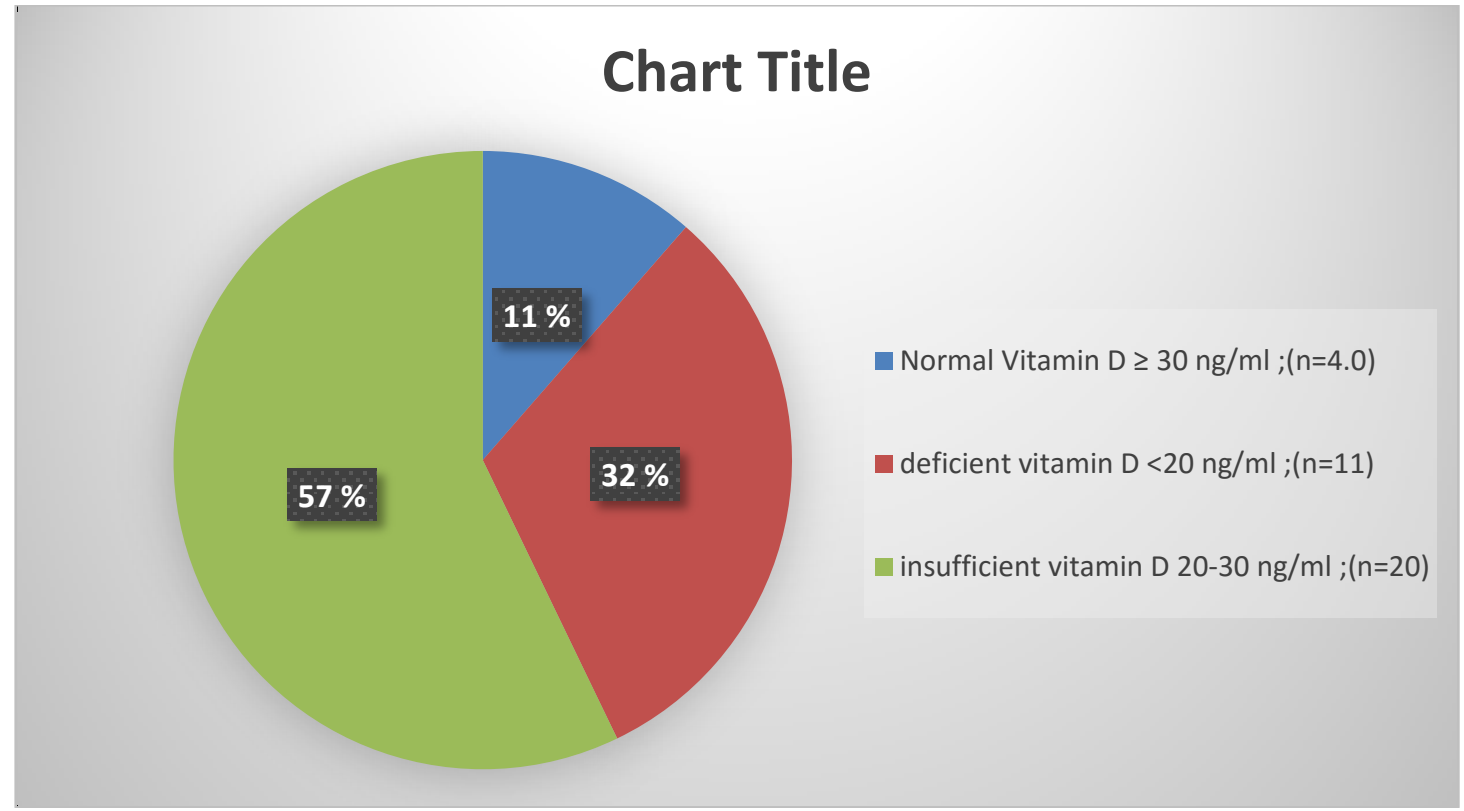

Fig. 1: Pie Graph of Vitamin D Levels in Infertile Women Group According to Different Concentration Categories.

BMI correlated negatively with Anti- Mullerian hormone level $(r=-0.78 ; \mathrm{p}<0.05)$ as shown in figure (2) 


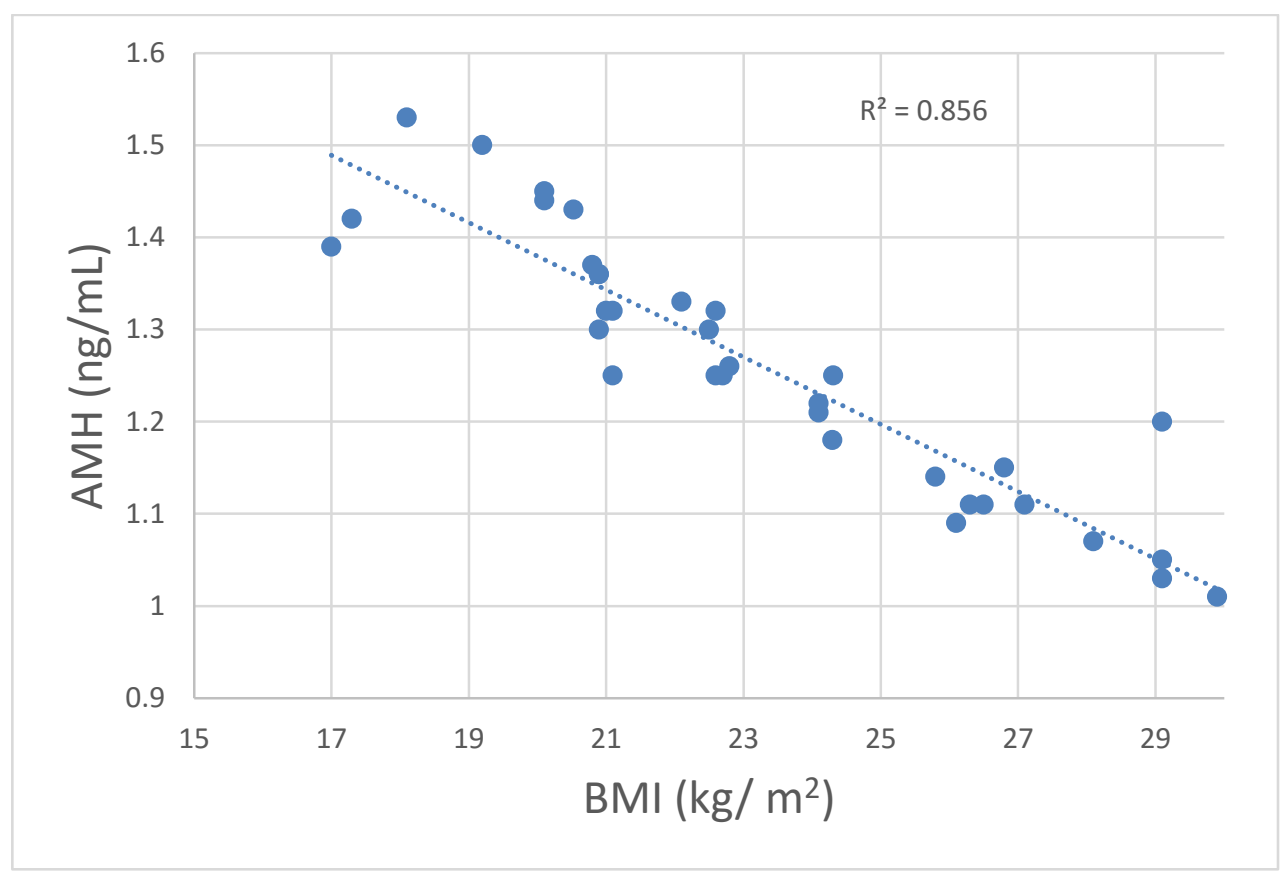

Fig. 2: Correlation between BMI and AMH In Infertile Group.

Figure (3) illustrates that there is a significant correlation between vitamin D and Anti- mullerian hormone levels in infertile women group $(\mathrm{r}=0.86 ; \mathrm{p}<0.05)$

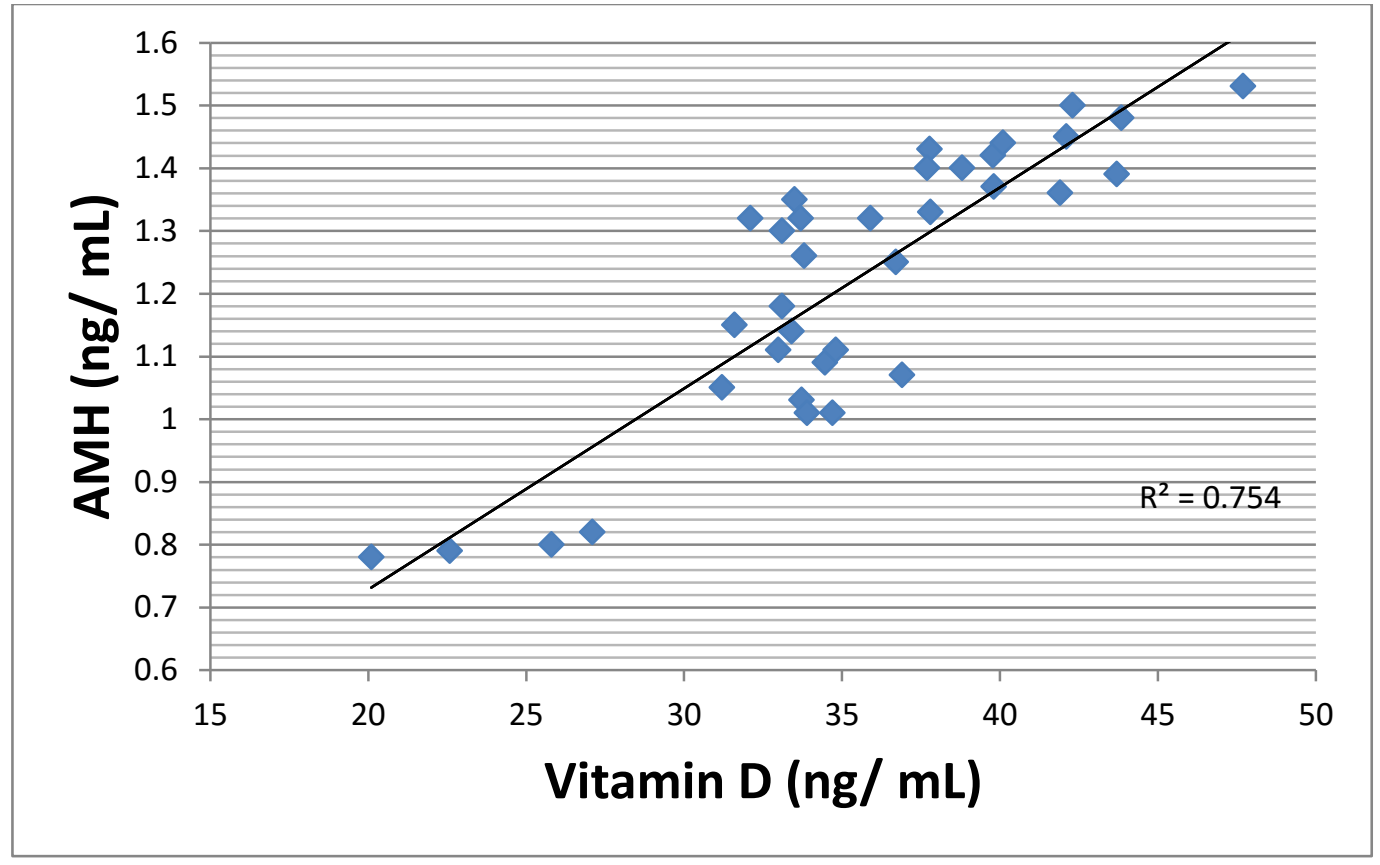

Fig. 3: Correlation between Vitamin D and AMH.

\section{Discussion}

Low vitamin D levels have been linked to an increased risk of cancer [20], autoimmune diseases, diabetes, cardiovascular diseases, and polycystic ovarian syndrome [20-23] indicating the importance of sufficient vitamin D levels. Although, there is no consensus an optimal vitamin D level, a level of $30 \mathrm{ng} / \mathrm{mL}$ can be considered to indicate sufficient vitamin D status [21].Many investigators reported that the prevalence of vitamin D insufficiency (20.1- 30 $\mathrm{ng} / \mathrm{ml}$ ) or deficiency (less than $20 \mathrm{ng} / \mathrm{ml}$ ) was $79 \%$ in a population of women undergoing in vitro fertilization [21], [24], [25], [29]. In this study (88.5\%) of infertile women showed vitamin D values below this recommended level (30 $\mathrm{ng} / \mathrm{ml}$ ). High levels of maternal vitamin D have been associated with improved fertility[26], lower rise of gestational diabetes [27], lower rise of cesarean section [28], improved birth outcomes such as birth weight and early growth [29, $30]$, of note, one study found the follicular fluid $25(\mathrm{OH}) \mathrm{D}$ increased the likelihood of clinical pregnancy of $7 \%$. And 
follicular fluid $25(\mathrm{OH}) \mathrm{D}$ was well correlated with serum levels [26]. It was hypothesized that vitamin D may improve ovarian steroidogenesis increased endometrial receptively [20], [31].

Throughout this study it was demonstrated that circulating vitamin D was positively correlated with serum AntiMullerian hormone levels (ovarian reserve marker) in female infertility group $(r=+0.86 ; p \leq 0.05)$. Recently many scientists declared that vitamin D was a target for AMH gene expression [13], [32].

The AMH gene was upregulated by vitamin D via functional vitamin D response elements that bind the vitamin $\mathrm{D}$ receptor [13], [32]. Because vitamin D induces the AMH gene [32] and because the vitamin D and AMH are positively correlated as shown in figure (3), it is possible to conclude that vitamin D contributes to AMH actions by increasing AMH production by granulosa cells.

The results of current study indicated that low vitamin D levels are significantly associated $(\mathrm{p}<0.002)$ with primary infertility women. This finding may be explained by that vitamin $\mathrm{D}$ has a biological plausible role in female reproduction.

In human ovarian tissue, vitamin D stimulated progesterone production by $13 \%$, estradiol production by $9 \%$ and estrone production by $21 \%$ [33]. On the other hand, vitamin D regulates human chorionic gonadotropin expression and secretion in human syncytiotrophoblasts [34], [35] and increases placental sex steroid production.

Previous studies have demonstrated that calcitriol promotes calcium transport in the placenta, stimulates placental lactogen expression, and regulates HOXA 10 protein (homeobox A10 protein) expression in human endometrial stroma cells [36]. HOXA 10 expression is important for the endometrial development, allowing uterine receptivity to implantation [37].

Our data might lead to new therapeutic approaches such as vitamin D supplementation in the treatment of female infertility. Throughout this study, a negative correlation was found between BMI value and vitamin D levels in both control and infertility women groups. This finding was similar to those reported previously. Panidis et al [38] found an inverse association of vitamin D with obesity as well as a BMI-dependent association with insulin resistance. There is evidence that low vitamin D levels are associated with obesity [39] and vice-versa low vitamin D intake might be an independent predictor of obesity [40].

There are however mechanisms beyond obesity that might explain the association of vitamin D deficiency with insulin resistance. First vitamin D may have a beneficial effect on insulin action by stimulating the expression of insulin receptor and thereby enhancing insulin responsiveness for glucose transport [41]. The vitamin D responsive element is found in the promoter of the human insulin gene [42] and transcription of the human insulin gene is activated by1,25 $(\mathrm{OH})_{2} \mathrm{D}_{3}$ [43].Second vitamin D regulates extracellular and intracellular calcium which is essential for insulin mediated intracellular processes in insulin-responsive tissues such as skeletal muscle and adipose tissue [41].

To our knowledge, this is the first study of measuring vitamin D in infertile Iraqi women. Our overall results suggest that decreasing serum vitamin D levels are associated directly and significantly with female infertility.

These results generally are consistent with those observed previously, Ozkan et al. showed higher pregnancy and implantation rates across tertiles of $25(\mathrm{OH})$ D3 in follicular fluid of 84 infertile women undergoing IVF and proposed follicular fluid $25(\mathrm{OH}) \mathrm{D} 3$ levels as an independent predictor to success of an IVF cycle [26]. From the results of this study, it was concluded that normal plasma vitamin D levels is important to maintain normal fertilizing ability and conceive.

\section{References}

[1] Luk J, Torrealday S, Neal Perry G, Pal L. Relevance of vitamin D in reproduction. Hum Reprod. 2012; 27:3015-3027. http://dx.doi.org/10.1093/humrep/des248.

[2] Anagnostis P, Karras S, Goulis DG. Vitamin D in human reproduction: a narrative review. Int J Clin Pract 2013; 67(3): 225- 235. http://dx.doi.org/10.1111/ijcp.12031.

[3] Lieben L, Carmeliet G, Masuyama R. Calcemic actions of vitamin D: effect on the intestine, kidney and bone. Best Pract Res Clin Endocrinol Metab 2011; 25: 561- 72. http://dx.doi.org/10.1016/j.beem.2011.05.008.

[4] Grundmann M, von Versen- Höynck F. Vitamin D- roles in women's reproductive health? Reproductive biology and endocrinology. 2011, 9: 146. http://dx.doi.org/10.1186/1477-7827-9-146.

[5] Alpert PT, Shaikh U. The effects of vitamin D deficiency on the endocrine and paracrine systems. Biol Res Nurs. 2007; 9(2): 117-129. http://dx.doi.org/10.1177/1099800407308057.

[6] Dokoh S, Donaldson CA, Marion SL, Pike JW, Haussler MR. The ovary a target for 1, 25-dihydroxyvitamin D3. Endocrinology 1983; 112(1): 200-206. http://dx.doi.org/10.1210/endo-112-1-200.

[7] Halloran BP, Deluca HF.Effect of vitamin D deficiency on fertility and reproduction capacity in the female rat. J. Nut 1980; 110(8): 15731580.

[8] Ruder EH, Hartman TJ, Blumberg J, Goldman MB. Oxidative stress and antioxidant exposure and impact on female fertility. Human reproduction update 2008; 14(2): 345-357. http://dx.doi.org/10.1093/humupd/dmn011.

[9] Hamade A, Bhanini S, Saade T, Fakih Y, Fakih C, Azzi R, Hazouri M, Rizk F. Vitamin D levels in serum, vitamin D receptor polymorphisms and semen quality correlations in Lebanon: A pilot cross- sectional study. Universal journal of public health 2014; 2(4): 118- 124.

[10] Poornima BN, Govindraju NL, Bhat SK. Vitamin D acts as bio- marker for predicting IVF success: A case study. International research journal of biological sciences 2014; 3(9): 97- 99 .

[11] Patel M, Jain S, Jain D, Patel B, Phanse N, Vyas P, Rathore P. Prevalence of different factors responsible for infertility. Res J Recent Sci 2012; 1: 207- 211.

[12] Lerchbaum E, Obermayer- Pietsch B. Vitamin D and fertility: a systematic review. Eur J Endocrinol 2012; 166: $765-778$. http://dx.doi.org/10.1530/EJE-11-0984. 
[13] Merhi OZ, Seifer BD, Weedon J, Adeyemi OHRN, Anastos KGTE, Young MKR, et al. Circulating vitamin D correlates with serum antimullerian hormone levels in late reproductive aged women. Women's Interagency HIV study. Fertil Steril 2012; 98: 228- 234. http://dx.doi.org/10.1016/j.fertnstert.2012.03.029.

[14] Vigier B, Tran D, Legeai L, Bezard J, Josso N. Origin of anti- mullerian hormone in bovine freemartin fetuses. J Reprod Fertil 1984; 70: 473479. http://dx.doi.org/10.1530/jrf.0.0700473.

[15] Saglam F, Onal ED, Erosy R, Koca C, Ergin M, Erel O, Cakir B. Anti- mullerian hormone as a marker of premature ovarian aging in autoimmune thyroid disease. Gynecol Endocrinol 2014, Early online: 1- 4.

[16] Van Rooij IA, Tonkelaar I, Broekmans FJ, Looman CW, Scheffer GJ, de Jong FH, Themmen AP, te Velde ER. Anti- mullerian hormone is a promising predictor for the occurrence of the menopausal transition. Menopause 2004; 11: 601-606. http://dx.doi.org/10.1097/01.GME.0000123642.76105.6E.

[17] Van Rooij IA, Broekmans FJ, te Velde ER, Fauser BC, Bancsi LF, de Jong FH, Themmen AP. Serum anti- mullerian hormone levels: a novel measure of ovarian reserve. Hum Reprod 2002; 17: 3065- 3071. http://dx.doi.org/10.1093/humrep/17.12.3065.

[18] Van Disseldorp J, Broekmans FJ, Peeters PH, Fauser BC, van der Schouw YT. The association between vascular function related genes and age at natural menopause. Menopause 2008; 15: 511-516. http://dx.doi.org/10.1097/gme.0b013e31814cec52.

[19] Szafarowska M, Molinska- Glura M, Jerzak MM. Anti- mullerian hormone concentration as a biomarker of pregnancy success or failure. Neuroendocrinology letters 2014; 35(4): 322- 326.

[20] Pilz S, Dobnig H, Winklhofer- Roob B, Riedmuller G, Fischer JE, Seelhorst U, et al. Low serum levels of 25- hydroxyvitamin D predict fatal cancer in patients referred to coronary angiography. Cancer Epidemiology, Biomarkers and Prevention 2008; 17: 1228 - 1233. http://dx.doi.org/10.1158/1055-9965.EPI-08-0002.

[21] Holick MF. Vitamin D deficiency. New England Journal of Medicine 2007; 357: 266- 281. http://dx.doi.org/10.1056/NEJMra070553.

[22] Pilz S, März W, Wellnitz B, Seelhorst U, Fahrleitner- Pammer A, Dimai HP, et al. Association of vitamin D deficiency with heart failure and sudden cardiac death in a large cross- sectional study of patients referred for coronary angiography. J Clin Endo Metabol 2008; 93: 39273935. http://dx.doi.org/10.1210/jc.2008-0784.

[23] Wehr E, Pilz S, Schweighofer N, Giuliani A, Kopera D, Pieber TR, Obermayer- Pietsch B. Association of hypovitaminosis D with metabolic disturbances in polycystic ovary syndrome. Eur J Endocrinol 2009; 161: 575- 582. http://dx.doi.org/10.1530/EJE-09-0432.

[24] Anifandis GM, Dafopoulos K, Messini CI, Chalvatzas N, Liakos N, Pournaras S, Messinis IE. Prognostic value of follicular fluid 25- OH vitamin D and glucose levels in the IVF outcome. Reprod Biol Endo 2010; 8: 91. http://dx.doi.org/10.1186/1477-7827-8-91.

[25] Garbedian K, Boggild M, Moody J, Liu KE. Effect of vitamin D status on clinical pregnancy rates following in vitro fertilization. Canadian Medical Association Journal 2013; 1(2): E77- E82. http://dx.doi.org/10.9778/cmajo.20120032.

[26] Ozkan S, Jindal S, Greenseid K, Shu J, Zeittian G, Hickmon C, Pal L. Replete vitamin D stores predict reproductive success following in vitro fertilization. Fertil Steril 2010; 94(4): 1314- 1319. http://dx.doi.org/10.1016/j.fertnstert.2009.05.019.

[27] Zhang C, Qiu C, Hu FB, David RM,van Dam RM, Bralley A, Williams MA. Maternal plasma 25- hydroxyvitamin D concentrations and the risk for gestational diabetes mellitus. PLoS one 2008; 3(11): e3753. http://dx.doi.org/10.1371/journal.pone.0003753.

[28] Merewood A, Mehta SD, Chen TC, Bauchner H, Holick MF. Association between vitamin D deficiency and primary cesarean section. J Clin Endocrinol Metab 2009; 94(3): 940- 945. http://dx.doi.org/10.1210/jc.2008-1217.

[29] Li L, Schriock E, Dougall K, Givens C. Prevalence and risk factors of vitamin D deficiency in women with infertility. Pacific Fertility Center, San Francisco, CA.

[30] Morley R, Carlin JB, Pasco JA, Wark JD. Maternal 25- hydroxyl vitamin D and parathyroid hormone concentrations and offspring birth size. J Clin Endocrinol Metabol 2006; 91(3): 906- 912. http://dx.doi.org/10.1210/jc.2005-1479.

[31] Vigano P, Lattuada D, Mangioni S, Ermellino L, Vignali M, Caporizzo E, et al. Cycling and early pregnant endometrium as a site of regulated expression of the vitamin D system. Journal of Molecular Endocrinology 2006; 36: 415- 424. http://dx.doi.org/10.1677/jme.1.01946.

[32] Malloy PJ, Peng L, Wang J, Feldman D. Interaction of the vitamin D receptor with a vitamin D response element in the mullerian- inhibiting substance (MIS) promoter: Regulation of MIS expression by calcitriol in prostate cancer cells. Endocrinology 2009; 150 : 1580 - 1587. http://dx.doi.org/10.1210/en.2008-1555.

[33] Parikh G, Varadinova M, Suwandhi P, Araki T, Rosenwaks Z, Poretsky L, et al. Vitamin D regulates steroidogenesis and insulin- like growth factor binding protein-1 (IGFBP-1) production in human ovarian cells. Hormone and Metabolic Research 2010; 42 : $754-757$. http://dx.doi.org/10.1055/s-0030-1262837.

[34] Barrera D, Avila E, Henandez G, Mendez I, Gonzalez I, Halhali A, et al. Calcitriol affects hCG gene transcription in cultured human syncytiotrophoblasts. Reproductive Biology and Endocrinology 2008; 6:3. (doi: 10.1186/1477-7827-6-3) http://dx.doi.org/10.1186/14777827-6-3.

[35] Barrera D, Avila E, Henandez G, Halhali A, Biruete B, Larrea F, et al. Estradiol and progesterone synthesis in human placenta is stimulated by calcitriol. Journal of Steroid Biochemistry and Molecular Biology 2007; 103: 529- 532. http://dx.doi.org/10.1016/j.jsbmb.2006.12.097.

[36] Du H, Daftary GS, Lalwani SI, Taylor HS. Direct regulation of HOXA10 by 1, 25-(OH) 2D3 in human myelomonocytic cells and human endometrial stromal cells. Molecular Endocrinology 2005; 19: 2222- 2233. http://dx.doi.org/10.1210/me.2004-0336.

[37] Bagot CN, Troy PI, Taylor HS. Alteration of maternal HOXA10 expression by in vivo gene transfection affects implantation. Gene Therapy 2000; 7: 1378- 1384. http://dx.doi.org/10.1038/sj.gt.3301245.

[38] Panidis D, Balaris C, Farmakiotis D, Rousso D, Kourtis A, Balaris V, et al. Serum parathyroid hormone concentrations are increased in women with polycystic ovary syndrome. Clinical Chemistry 2005; 51: 1691- 1697. http://dx.doi.org/10.1373/clinchem.2005.052761.

[39] Hahn S, Haselhorst U, Tan S, Quadbeck B, Schmidt M, Roesler S, et al. Low serum 25- hydroxyvitamin D concentrations are associated with insulin resistance and obesity in women with polycystic ovary syndrome. Experimental and Clinical Endocrinology and Diabetes 2006; 114: 577- 583. http://dx.doi.org/10.1055/s-2006-948308.

[40] Kamycheva E, Joakimsen RM, Jorde R. Intakes of calcium and vitamin D predict body mass index in the population of Northern Norway. Journal of Nutrition 2003; 133: 102- 106.

[41] Pittas AG, Lau J, Hu FB, Dawson- Hughes B. The role of vitamin D and calcium in type 2 diabetes. A systematic review and meta-analysis. Journal of Clinical Endocrinology and Metabolism 2007; 92: 2017- 2029. http://dx.doi.org/10.1210/jc.2007-0298.

[42] Maestro B, Davila N, Carranza MC, Calle C. Identification of a vitamin D response element in the human insulin receptor gene promoter Journal of Steroid Biochemistry and Molecular Biology 2003; 84: 223- 230. http://dx.doi.org/10.1016/S0960-0760(03)00032-3.

[43] Maestro B, Molero S, Bajo S, Davila N, Calle C. Transcriptional activation of the human insulin receptor gene by 1,25- dihydroxyvitamin D3. Cell Biochemistry and function 2002; 20: 227- 232. http://dx.doi.org/10.1002/cbf.951. 